\title{
Experimental Study of the Effectiveness of College Students' Vocational Training in Conditions of Social Partnership
}

\author{
Aida V. Kiryakova ${ }^{a}$, Aleksandr N. Tretiakov ${ }^{b}$, Vadim V. Kolgac, \\ Olga F. Piralova ${ }^{d}$, and Bika B. Dzhamalova ${ }^{e}$
}

aOrenburg State University, RUSSIA; bVyatka College of Economics, Statistics and Informatics, RUSSIA; 'Krasnoyarsk State Pedagogical University named after V. P. Astafyev, RUSSIA; dOmsk State Transport University, RUSSIA; eNorth-Caucasus Institute (branch) of All-Russian State University of Justice (RPA Russian Ministry of Justice) in Makhachkala, RUSSIA.

ABSTRACT

This article is focused on the development of organizational and pedagogical conditions of college students' vocational training in terms of social partnership and experimental study of their effectiveness. The leading methods in the study of this problem are the observations, conversations, monitoring, questioning, psychological testing and pedagogical experiment, allowing checking of the effectiveness of the proposed organizational and pedagogical conditions of students' vocational training in terms of social partnership. The article deals with the role of social partnership of colleges and enterprises; identifies organizational and pedagogical conditions of students' vocational training in terms of social partnership between the college and the company; justifies forms of cooperation between the educational institutions and its social partners; identifies criteria for production and pedagogical management of students' vocational training in the conditions of Social Partnership between the college and the company; proves the effectiveness of college students' vocational training in the conditions of social partnership. The paper submissions are of a definite value in the organization of social partnership in the system of secondary and higher vocational education.

KEYWORDS

College; students; vocational training; social partnership
ARTICLE HISTORY

Received 15 September 2015 Revised 10 November 2015 Accepted 22 February 2016

\section{Introduction}

\section{Urgency of the problem}

In the current socio-economic conditions, more and more the issue actualized how to form a new system of relations between educational institutions and employers. Social partnership helps all participants to join in the search for 
optimal ways to implement as their own interests so the general economic interest, consisting in the training of qualified personnel, demanded by labor market. The government, business and educational institutions long ago have been trying to enter the "triple alliance", to improve the quality of primary and secondary vocational education (Shaidullina et al., 2015a, b, c; Masalimova et al., 2014).

And it has two aspects: how to train a decent professionals and how to make them stay at the company.

Professional level of the staff, which was trained by educational institutions, met the requirements of high-tech industry until recently because it is constantly being upgraded. The current situation shows that employers are required to take a direct part in the future professionals' and specialists' training for modern company to achieve further industrial growth. And this problem doesn't belong to only individual company, but it is also nationwide, because human resources are not only skilled workers but also the well-being of each of them, respectively, the safety and well-being of the country as a whole (Vlasova, Kirilova \& Sabirova, 2015; Sakhieva et al., 2015; Baklashova, 2014; Ganieva et al., 2014; Zaripova et al., 2014).

Growing process of the industrial progress obliges the institutions of primary and secondary vocational education to prepare not the apprentices but true professionals, possessing high production and common culture, the ability and the desire to the development of technological and organizational innovations.

Union of industrialists, representatives of small and medium business as the main purpose of social partnership sees joint implementation of specific measures aimed at increasing of the effectiveness of vocational education. Each side seeks its own path of development and forms of social partnership.

\section{The role of social partnership between colleges and enterprises}

Sustainable development of colleges, as well as any other socio-economic systems is connected with the ongoing modernization of their activities, the search for new, more effective partners, the introduction of innovations based on social partnership in the educational process. Innovations in the form of new specialties in which there is a need for the partners and the labor market in general, educational curricula and training plans agreed with the partner organizations enable colleges to find new niches for the implementation of educational services, improve their quality, use all available reserves and potential. Management of sustainable development of colleges should be based on the principles of openness, adaptability to changing conditions, activity, learning, reflection and should be aimed at long-term results.

Analysis of trends in the market of educational services, as well as practical experience suggest that the development of networks of partnerships between colleges and various companies provide sustainable development not only of the cooperation of members, but also contribute to the development of innovative component of regions and country in the whole (Lysov, 2013).

The effectiveness of the interaction of colleges with industrial, financial, industrial and transport business structures is unquestionable in terms of the 
formation of professional standards, monitoring of the quality of education, the creation and maintenance of the material base of educational institutions. The most effective form of cooperation today is the social partnership. In the broad sense "partnership" means a variety of forms of cooperation and is presented as a coordination of the educational systems with other production systems by new forms of relationships.

The partnership opens additional opportunities for college:

- permanent access to labor market's information that allows refining of the structure of professions and trades, the volume of their training;

- taking into account of the employers' requirements on the content of the training of specialists through the joint development of training curricula and plans;

- organization of students' practice on the equipment involved in the real sector of the service industry;

- systematic training of college teachers in companies to become familiar with the latest equipment;

- assessment of the quality of training by independent experts;

- professionals' targeted training for specific companies and others.

\section{Literature Review}

Accumulation and generalization of the experience of social partnership in vocational education laid the foundation for the theory of social partnership (Polyakova, 2007; Zaitseva, 2006; Mikheev, 2001; Smirnov \& Tkachenko, 2004; Tkachenko et al., 2003; Hofmann et al., 2000). In pedagogical science the main directions and strategies for the development of social partnership in the secondary vocational education system are defined (Korchagin \& Sohabeev, 2006; Fadeyev, 2009; Chitalin, 2008). Some aspects of social partnership of colleges are covered in the papers on the theory of management by training and development of staff (Klimov, 2004; Markova, 1996; Shadrikov, 1996; Schedrovitsky, 1993) and on the area of socialization and professional adaptation of students (Biebrich, 1990; Kolobkov, 2007; Rozhenko, 2006; Brudnyi, 1976; Glinkina, 2002; Legoshina, 2005; Mnatsakanyan, 2004; Baklashova, Galishnikova \& Khafizova, 2015; Vlasova, Kirilova \& Curteva, 2016). However, it should be noted that mainly problems are discusses about cooperation between college and industry.

The works of these and other authors allow studying of important aspects of the problem of social partnership as a factor of quality of vocational training and identifying of prospects for its solution. Analysis of theoretical studies, best and mass practices shows that the problem of interaction between colleges and social partners in the quality's ensuring of professionals' training is very sharp and has not yet become a subject of special pedagogical research. 


\section{Materials and Methods}

During the study the following methods were used

- theoretical methods: system analysis, synthesis, generalization, theoretical analysis of philosophical, pedagogical, psychological, scientific, methodical and technical literature on the research problem;

- empirical methods: observation, conversations, monitoring, questioning, psychological testing, experiment.

Experimental work took place in several stages.

The aim of ascertaining stage of the experiment (2013-2014) was to determine the structure and efficiency of the traditional managerial system of students' vocational training.

At the forming stage (2014-2015) an analysis of the regional labor market was done, the legal framework for the cooperation of college with the social partners was developed; forms of social partnership of college were defined, employers were involved in the organization of the managerial and the educational processes, the development of qualifications' requirements for verification procedures of professional knowledge and skills. The purpose of the control stage (2015-2016) was to check the efficiency of the developed pedagogical conditions for production and pedagogical management of students' vocational training.

\section{Results}

Social Partnership of college and company is based on the following principles: equality of the parties, democracy, allowing any party to take the initiative, to justify its position; regulatory support of the participants' activities; voluntary acceptance of obligations by the parties and the mandatory of their implementation.

\section{Functions and organizational conditions of social partnership between college and company}

The main functions of production and pedagogical management are focused on providing of the most effective students' vocational training at minimal cost and time and include:

1) providing of labor market with the required quantities of competitive, mobile, highly skilled workers and mid-level professionals,

2) promotion to the successful socialization of the individual of the student, in order to achieve the student's self-determination, active life activities, quick adaptation to innovations of modern high-tech industry.

Table 1 shows the basic conditions for social partnership between college and company and the parties' activities. 
Table 1. The organizational conditions of social partnership of college and company

\begin{tabular}{|c|c|c|}
\hline College & $\begin{array}{l}\text { Conditions of } \\
\text { social partnership }\end{array}$ & Company \\
\hline $\begin{array}{l}\text { Orders of the director: on } \\
\text { the preparation of } \\
\text { students for training in the } \\
\text { company, on students' } \\
\text { sending to the company }\end{array}$ & $\begin{array}{l}\text { The Social Partnership } \\
\text { Agreement }\end{array}$ & $\begin{array}{l}\text { The order of the enterprise on the } \\
\text { admission of students for vocational } \\
\text { training }\end{array}$ \\
\hline $\begin{array}{l}\text { Making and approval of the } \\
\text { schedule for students' } \\
\text { vocational training in the } \\
\text { company's environment }\end{array}$ & $\begin{array}{l}\text { Schedule of students' } \\
\text { vocational training in the } \\
\text { company with deadlines, } \\
\text { stages, offices' } \\
\text { departments, workplaces }\end{array}$ & $\begin{array}{l}\text { Participation in the making and } \\
\text { approval of the schedule for } \\
\text { students' vocational training in the } \\
\text { enterprise }\end{array}$ \\
\hline $\begin{array}{l}\text { Development, discussion, } \\
\text { approval of a detailed } \\
\text { curriculum of students' } \\
\text { vocational training, } \\
\text { learning goals' and } \\
\text { objectives' setting in the } \\
\text { company }\end{array}$ & $\begin{array}{l}\text { Agreed and approved } \\
\text { detailed curriculum of } \\
\text { students' vocational } \\
\text { training in the company }\end{array}$ & $\begin{array}{l}\text { Participation in the development and } \\
\text { approval of the detailed curriculum } \\
\text { of students' vocational training in } \\
\text { the company }\end{array}$ \\
\hline $\begin{array}{l}\text { Distribution of students for } \\
\text { jobs, their instructing, } \\
\text { making of scheduling for } \\
\text { inspections, conducting of } \\
\text { staff meetings, students' } \\
\text { counseling }\end{array}$ & $\begin{array}{l}\text { Resource (teaching- } \\
\text { material, teaching- } \\
\text { methodical, human } \\
\text { resources, financial and } \\
\text { other.) provision of } \\
\text { students' vocational } \\
\text { training in the company }\end{array}$ & $\begin{array}{l}\text { Instruction of labor safety at the } \\
\text { plant, providing of securing mentors } \\
\text { for students, provision of students } \\
\text { with specials clothing, tools, jobs, } \\
\text { technical documentation, } \\
\text { implementation of work according to } \\
\text { the curriculum, students' } \\
\text { independent work at paid jobs }\end{array}$ \\
\hline $\begin{array}{l}\text { The contest for the title of } \\
\text { "Best in Profession", final } \\
\text { qualification exams }\end{array}$ & Employment of graduates & $\begin{array}{l}\text { Examination for admission to } \\
\text { independent work, final qualification } \\
\text { exams }\end{array}$ \\
\hline
\end{tabular}

Pedagogical conditions for management of students' vocational training in terms of social partnership "college - company"

The study identifies and justifies pedagogical conditions for optimization of management of students' vocational training in terms of social partnership "college - company":

1) organization of marketing research of the regional labor market;

2) establishment of a regional bank of social partners in the context of the prepared occupations and professions;

3) modern material and technical support of the training process;

4) demand for graduates in the labor market;

5) increase students' motivation to learn, master the profession (specialty);

6) involvement of employers and other social partners in the development of qualifications' requirements, procedures of knowledge's, professional abilities' and skills' verification;

7) increasing of the educational and professional level of teachers. 


\section{Forms of cooperation of educational institutions with social partners}

The study reveals the forms of cooperation of educational institutions with the social partners: students' practical training at the actual workplaces, conducting of some classes for students by the representatives of the industry ("guest lecturers"); employers' participation in the assessment of students, employers' participation in the development and review of training-curricular documentation, assessment of the labor market; teachers' training at real workplaces, employers' participation in professional skills' competitions, student conferences, decades by specialties, etc., joint participation in exhibitions, improvement of industrial professionals' qualification in educational institution, employment of graduates, the organization of the Board of Trustees, industrial (sector) Councils on social partnership.

The most promising form of social partnership are the regional advisory councils, which include representatives of educational institutions, employers, professional associations, employment services, regional authorities of industry and education. Advisory councils are created with a view to improve the content of vocational education and to promote to corporate democratic relations' development between educational institutions and the social partners at the regional level

Criteria for production and pedagogical management of students' vocational training in conditions of social partnership "college-company"

Criteria for production and pedagogical management of students' vocational training in conditions of social partnership "college-company" are determined in accordance with a dynamic model of a specialist. Dynamic professional model defines the main stages in the development of students' educational and professional activities, as in the training process in the educational institution so in company's environment:

- 1 stage - the formation of educational activities;

- 2 stage - the foundations' formation of professional activities;

- 3 stage - the formation of graduates' readiness for professional work in conditions of the company.

The specific distribution of stages by years of studying is determined depending on the specific specialty.

A student in the process of vocational training is under the managerial actions not only from the college, as it was during the traditional managerial system, but also from the company, by interacting with the engineering and technical personnel, using of material and technical base at the time of the industrial practice.

\section{The course and results of the experiment}

To assess the quality of professionals' training a complex task was developed in Almetyevsk Oil College including theoretical, practical and professional unit. The theoretical block included questions on 10 academic disciplines, forming professional knowledge. Practical unit was aimed to manufacture with the use of the machine on the drawing given a detail of the complexity corresponding to the 2-3 category of a worker. Professional unit consisted of two parts: the development of the technological process of the manufacturing the part 
manually and performing of the same process with the application of modern computer-aided design systems. For each unit the rating scales were developed to assess objectively the performance of tasks and get the total score.

Complex task was examined by expertize in JSC Tatneft and Almetyevsk Oil College and received a positive opinion. The results of experimental data processed are shown in Tables 2-5.

Table 2. Demand for graduates in the labor market (the control group)

\begin{tabular}{ccccccc}
\hline Year & Trained, & Employed, & The need in & \multicolumn{3}{c}{ The quality of training, people } \\
\cline { 5 - 7 } & people & persons & people & High & Average & Low \\
\hline 2015 & 37 & 14 & 23 & 12 & 17 & 8 \\
2014 & 37 & 8 & 19 & 5 & 21 & 11 \\
2013 & 42 & 18 & 29 & 11 & 18 & 13 \\
2012 & 59 & 14 & 23 & 24 & 26 & 9 \\
\hline
\end{tabular}

Table 3. Demand for graduates in the labor market (the experimental group)

\begin{tabular}{ccccccc}
\hline Year & Trained & \multicolumn{2}{c}{ Employed,} & The need in & \multicolumn{3}{c}{ The quality of training, people } \\
\cline { 5 - 7 } & people & people & people & High & Average & Low \\
\hline 2015 & 17 & 17 & 17 & 13 & 4 & - \\
2014 & 17 & 17 & 17 & 14 & 3 & - \\
2013 & 15 & 15 & 15 & 15 & - & - \\
2012 & 25 & 24 & 25 & 14 & 9 & 2 \\
\hline
\end{tabular}

The comparison of the results presented in tables 2 and 3 shows that over the past three years all graduates of the experimental group were demanded and employed, and graduates' staying in the company on specialty was $100 \%$ (tables 4 and 5), while similar indicators of control group were much lower.

Table 4. Staying of graduates in the company (control group)

\begin{tabular}{ccccccc}
\hline Year & Trained & \multicolumn{2}{c}{$\begin{array}{l}\text { Employed, } \\
\text { people }\end{array}$} & \multicolumn{2}{c}{ The need in } & \multicolumn{3}{c}{ The quality of training, people } \\
\cline { 5 - 7 } & people & people & High & Average & Low \\
\hline 2015 & 14 & 12 & 12 & - & - & - \\
2014 & 8 & 5 & 3 & 5 & - & - \\
2013 & 18 & 10 & 9 & 4 & 5 & - \\
2012 & 14 & 7 & 5 & 2 & 3 & 4 \\
\hline
\end{tabular}

Table 5. Staying of graduates in the company (experimental group)

\begin{tabular}{ccccccc}
\hline Year & \multirow{2}{*}{$\begin{array}{c}\text { Trained, } \\
\text { people }\end{array}$} & \multirow{2}{*}{$\begin{array}{c}\text { Employed, } \\
\text { people }\end{array}$} & \multirow{2}{*}{$\begin{array}{c}\text { The need in } \\
\text { people }\end{array}$} & \multicolumn{3}{c}{ The quality of training, people } \\
\cline { 5 - 7 } & 17 & 17 & 14 & High & Average & Low \\
\hline 2015 & 17 & 17 & 2 & 15 & - & - \\
2014 & 15 & 15 & 1 & 2 & 12 & - \\
2013 & 24 & 24 & 5 & 2 & 1 & - \\
2012 & 24 & &
\end{tabular}

Thus, analysis of data in Tables 2,3,4,5 conclude that the indicators in the experimental groups were statistically better than in control groups, which indicates on a greater effectiveness of training in company's environment, in comparison with the conventional training in institution's environment. 


\section{Discussions}

The educational institution today has more social partners, the interaction with which also to a large extent influences the success of a competent professional's formation. These include representatives of local authorities, parents of students, secondary schools, universities, post-graduate educational system, and others. What are the interests, needs and requirements of these entities of social partnership? How should they affect the objectives, content and technology of specialists' training in college? These and other questions are out of sight of many researchers.

The study of social partnership's practices in the system of vocational education shows that successfully developing vocational schools and colleges are making their success not only due to the optimum inclusion in the process of specialist's training of internal resources of the institution, but also the opportunities of entities of labor markets and educational services, as well as government and public structures, stakeholders (governments, companies and institutions, schools, parents, students, teachers, and others).

In some colleges of Russia an interesting experience of a successful realization of the idea of social partnership has been accumulated as a condition for providing of the accessibility and quality of secondary vocational education in small towns and rural areas. Its essence is to create a college branches in the rural district centers, which becomes the center for integration of all social partners interested in skilled workers and professionals' training for the needs of the village. The graduates of the branches tend to stay to work in the village. These systems operate with the support of local administrations and the education authorities. However, they have not been yet the object of theoretical understanding and synthesis in the form of thesis research.

Analysis of the theory and practice of social partnership in the secondary vocational educational system allows to establish the existence of a contradiction between the fact that in modern conditions of colleges' development the social partnership becomes objectively necessary condition for improving of the quality of specialists' training, on the one hand, and the underdevelopment of the organizational and pedagogical conditions of the social partnership's implementation as a condition to improve the quality of specialist' training - on the other hand.

\section{Conclusion}

Thus, the paper points out that the modern vocational education should be based on the study of professions' supply and demand in the labor market, their prospects in a specific region based on the forecast of its economic development; qualification requirements to the profession (basic knowledge, abilities, skills, i.e. basic professional competences, additional professional competences, specific regional requirements, etc.); modern material and technical support of the training process (equipment, raw materials, new technologies and methods of production); fundamentally different, independent from the education, training's quality assessment with necessarily involving of the employer; changing of the 
approaches to the employment of college graduates (they must either come into the industry, or to return the money spent on their training); analysis of the graduate's real success (the fact how is developed his professional career, how the specialist's self-realization is carried out in the profession influence the rating of the educational institution).

Analysis of the experimental research data suggests that performance in the experimental groups of students, in which additional tasks were introduced and worked out at the companies, became statistically better than in control groups, indicating that the greater effectiveness of training took place in terms of production, in comparison with traditional training in the educational institution.

\section{Disclosure statement}

No potential conflict of interest was reported by the authors.

\section{Notes on contributors} Russia.

Aida V. Kiryakova is PhD, Professor of Orenburg State University, Orenburg,

Aleksandr N. Tretiakov is PhD, Associate Professor of Vyatka College of Economics, Statistics and Informatics, Kirov, Russia.

Vadim V. Kolga is PhD, Professor of Krasnoyarsk State Pedagogical University named after V. P. Astafyev, Krasnoyarsk, Russia. Russia.

Olga F. Piralova is PhD, Professor of Omsk State Transport University, Omsk,

Bika B. Dzhamalova is PhD, Professor of North-Caucasus Institute (branch) of AllRussian State University of Justice (RPA Russian Ministry of Justice) in Makhachkala, Makhachkala, Russia.

\section{References}

Baklashova, T. (2014) Managers' Professional Training in Russia: Syllabus and Technologies. Procedia - Social and Behavioral Sciences, 152, 1057-1061.

Baklashova, T. A., Galishnikova, E. M., Khafizova, L. V. (2015) The Effects of Education on Tolerance: Research of Students' Social and Ethnic Attitudes. Mediterranean Journal of Social Sciences, 6(1 S3), 335-340.

Biebrich, P. P. (1990) Motivational aspects of adaptation of students to the educational process in high school. Chisinau: Lonus. 175p.

Brudnyi, V. I. (1976) Professional and socio-psychological adaptation of students and young professionals. Moscow: Eksmo. 241p.

Chitalin, H. A. (2008) The contradictions of modernization of vocational education system in the conditions of formation of market relations: education, business partners or rivals. Vocational education, 4, 17-19.

Fadeev, S. A. (2009) Social college partnerships with employers as a condition for improving the quality of training highly qualified specialists. Vocational education, 5, 62 -66.

Ganieva, Y. N., Azitova, G. S., Chernova, Y. A., Yakovleva, I. G., Shaidullina, A. R., Sadovaya, V. V. (2014) Model of High School Students Professional Education. Life Science Journal, 11(8s), 1097-8135.

Glinkina, O. V. (2002) Adaptation freshmen. Vocational Education, 9, 11 - 13.

Hofmann, N. G., Eneke, B., Baydenko, V. I. (2000) Strategic plan of social dialogue in the contemporary professional education in the Russian Federation. Riga: Delphi. 437p.

Klimov, E. A. (2004) Psychology of professional's self-determination. Moscow: Logos. 304p. 
Kolobkov, V. F. (2007) Independent educational work as the factor of social and professional adaptation of college students (Unpublished master's thesis). Moscow: Academia. 226p.

Korchagin, E. A. \& Sohabeev, V. M. (2006) Social partnership in the secondary vocational education. Specialist, 3, 14- 17.

Legoshina, I. M. (2005) Professional adaptation as a means of forming competitive students of technical college (Unpublished master's thesis). St. Petersburg: Peter. 237p.

Lysov, I. A. (2013) Educational complexes as a factor of sustainable development of the university, business and region. Educational Technology, 3, 73-84.

Markova, A. K. (1996) Psychology of professionalism. Moscow: Drofa. 310p.

Masalimova, A. R., Zakirova, V. G., Chernova, Y. A., Drovnikov, A. S., Shaidullina, A. R. \& Sakhieva, R. G. (2014) Structure and content of mentors psychological and pedagogical training curriculum. Life Science Journal, 11(7s), 381-386.

Mikheev, V.A. (2001) Basics of Social Partnership. Moscow: Examination. 448p.

Mnatsakanyan, I. A. (2004) Adaptation of students in the new socio-cultural conditions (Unpublished master's thesis). Yaroslavl. 242p.

Polyakova, S. N. (2007) Social partnership in vocational education. Vocational education, 1, 7 -8

Rozhenko, N. N. (2006) Professional adaptation of students of average special educational institution in the process of extracurricular work (Unpublished master's thesis). Moscow: Academia. 206p.

Sakhieva, R. G., Majkova, L. V., Emelyanova, M. V., Gavrilova, N. G., Sharonova, E. G., Gatina, A. R., Pavlova, N. A., Baklashova, T. A. (2015) The Supplementary Education Teacher's Portfolio: Essence, Functions, Structure and Design Principles. Mediterranean Journal of Social Sciences, 6(2 S3), 84-90.

Schedrovitsky, G. P. (1993) Essays on the philosophy of education. Moscow: Litcon. 226p.

Shadrikov, V. D. (1996) Psychology of human activities and abilities. Moscow: Publishing. Corporation "Logos". 320p.

Shaidullina, A. R., Krylov, D. A., Sadovaya, V. V., Yunusova, G. R., Glebov, S. O., Masalimova, A. R. \& Korshunova, I. V. (2015c) Model of Vocational School, High School and Manufacture Integration in the Regional System of Professional Education. Review of European Studies, $7(1), 63-67$.

Shaidullina, A. R., Ishmuradova, A. M., Maksimova, E. V., Yevgrafova, O. G., Derdizova, F. V., Baklanov, P. A., Bagateeva, A. O. (2015a) The Implementation of the Cluster Approach in the Regional System of Vocational Education. Review of European Studies, 7(4), 66-72.

Shaidullina, A. R., Morov, A. V., Morova, N. S., Petrova, T. N., Kirillova, O. V., Kirillova, T. V., Riazantzeva, I. M. (2015b) The Features of Social Partnership as a Mechanism for the Integration of Education and Production. Review of European Studies, 7(3), 292-297.

Smirnov I. P., \& Tkachenko I. P. (2004) Social partnership: what will happen to the employer? Moscow: Logos. 332p.

Tkachenko, E. V., Safonov, E. G., Panina, L. P., Fishukova, O. P. (2003) Social Partnership vocational education institutions. Ekaterinburg: Publishing House of the Russian Academy of Sciences. 330p.

Vlasova, V. K., Kirilova, G. I., Curteva O. V. (2016) Matrix classification of information environment algorithms application in the educational process. Mathematics Education, 11(1), 165-171.

Vlasova, V. K., Kirilova, G. I., Sabirova, E. G. (2015) Functioning of information educational environment: Meta dynamic approach. Review of European Studies, 7 (5), 25-30.

Zaitseva, I. B. (2006) The role of social partnership in the preparation of the competitive expert. Vocational education, 5, 5-6.

Zaripova, I. M., Shaidullina, A. R., Upshinskaya, A. Y., Sayfutdinova, G. B., Drovnikov, A. S. (2014) Modeling of Petroleum Engineers Design-Technological Competence Forming in PhysicalMathematical Disciplines Studying Process. American Journal of Applied Sciences, 11(7), 10491053. 